\title{
Temporal Changes of Plasma Erythropoietin Level in Hypobaric Hypoxic Mice and the Influence of an Altered Blood Oxygen Affinity
}

\author{
Satoshi Shimizu, Susumu SaKata, Yasunori Enoki, Yoshimi Ohga, \\ Izumi OKI, and Hisaharu KoHzUKI \\ Second Department of Physiology, Nara Medical University, \\ Kashihara, Nara, 634 Japan
}

\begin{abstract}
Temporal changes of plasma erythropoietin (Epo) in mice exposed to hypobaric hypoxia were studied by a fetal mouse liver cell culture method. Since a colony formation inhibitory activity was found in the mouse plasma, thirteen pretreatment procedures for bioassay were compared and the procedure of shaking with chloroform followed by dialysis was concluded to be the best. When normal mice $\left(P_{50}=40.4 \pm 2.2\right.$ Torr) were exposed to hypoxia of 350 Torr, the plasma Epo level was elevated, with peak at the 2nd to 3 rd day, and afterwards declined gradually. On the contrary, cyanated mice $\left(P_{50}=30.1 \pm 1.5\right.$ Torr $)$ showed much less of the Epo response when exposed to 350 Torr. Under 200 Torr hypoxia, both mice exhibited a similar and remarkable extent of the response. These results suggest that the renal Epo-producing tissue or its oxygen-sensing system is less hypoxic in cyanated mice than in normal mice under 350 Torr, and that the physiologically optimal oxygen affinity of blood is variable depending on hypoxic degrees. The fact that the inhibitory activity showed an inverse temporal change to that of Epo, suggested a possible important role of this activity in the regulation of erythropoiesis under hypoxia.
\end{abstract}

Key words: erythropoietin, hypobaric hypoxia, blood oxygen affinity, cyanate, erythroid colony inhibitor(s).

It is necessary for living organisms to maintain an appropriate red cell mass with regard to sufficient oxygen delivery to tissues. In this context, the role of erythropoietin (Epo), an erythroid stimulating factor, is very important to compensate for blood loss due to red cell life span.

Many factors are reported to be involved with the regulation of Epo production (JelkmanN, 1986a, b), and hypoxia is considered to be the most essential and basic 
stimulus (JELKMANN, 1986a, b). But, the quantitative relationship between hypoxia and Epo production remains to be examined. For example, although a rapid increase in plasma Epo is usually observed after hypoxic exposure (FINNE, 1965; ABBRECHT and LitTell, 1972; Russell and Keighley, 1972; Schooley and MahlmanN, 1975; DUNN et al., 1976, 1980; SCARo et al., 1984), the peak times range widely from $8 \mathrm{~h}$ (SCARo et al., 1984) to 2 days (DuNN et al., 1976, 1980) in mice. These variations have been ascribed to the differences of sex (RuSSELL and KeIGHLEY, 1972), strain (Russell and KeIGHLey, 1972), as well as Epo assay method used.

Here we intended to clarify the precise temporal pattern of plasma Epo changes when mice were exposed to hypobaric hypoxia. Furthermore, we verified the general contention that the higher oxygen affinity of blood is advantageous for oxygen transport under severe hypoxia (LAHIRI, 1975; HeBBEL et al., 1978), using plasma Epo level as a keen index for tissue hypoxia. As the importance of inhibitory factor(s) in the regulation of erythropoiesis has become recently appreciated (NAJMAN et al., 1987), the temporal pattern in hypoxic mice was also examined.

\section{MATERIALS AND METHODS}

Plasma erythropoietin assay. The fetal mouse liver cell culture method, which was developed in this laboratory (SAKATA et al., 1987) and requires only $10 \mu \mathrm{l}$ of plasma sample, was used. Sheep plasma Epo step 3 (Connaught, $200 \mathrm{IU}$ in $61 \mathrm{mg}$ ) was used as standard Epo.

Plasma pretreatment. Heparinized blood was obtained from inferior caval vein. Plasma was separated by centrifugation at $3,000 \mathrm{rpm}$ for $15 \mathrm{~min}$ and stored at $-90^{\circ} \mathrm{C}$ until use. Since an erythroid inhibitory activity was found in raw murine plasma, the following procedures were examined for their efficiency to remove the inhibitor(s): treatment by chloroform (GRANSTRÖM, 1972), ether (CHAN et al., 1971), dialysis (SAKATA et al., 1987), heating (SAKATA et al., 1987), acidification (SAKATA et al., 1987), and boiling (SAKATA et al., 1987). Freezing and thawing procedure: Plasma was frozen and thawed multiple times (once to 10 times). DEAE-cellulose chromatography: Plasma was loaded onto the column $(0.4 \times 7 \mathrm{~cm})$ of DEAEcellulose (Whatman, DE-52) equilibrated with $0.025 \mathrm{~m}$ acetate buffer ( $\mathrm{pH} 4.8$ or 5.2). The column was first eluted with the same buffer until $A_{280}$ of the eluates returned to baseline, and then with $1.0 \mathrm{M} \mathrm{NaCl}-0.1 \mathrm{M}$ phosphate buffer ( $\mathrm{pH} 7.0$ ) These fractions were dialyzed overnight against distilled water and lyophilized. These pretreatments were carried out singly or in combination. The resultant plasma was sterilized through Millipore filter (SJHV013NS, pore size $0.45 \mu \mathrm{m}$ ) and frozen at $-90^{\circ} \mathrm{C}$ until use.

Assay of erythroid colony-inhibiting factor(s) in plasma. Culture medium containing Epo $(250 \mathrm{mU} / \mathrm{ml})$ for maximum erythroid colony formation was used; and the extent of decrease in colony formation when untreated plasma samples were added to it was calculated as the inhibitory activity.

Preparation of mice with high oxygen-affinity blood. Cyanate, when 
administered, has been shown to react mainly with the $\alpha$-amino groups of $\mathrm{Hb}$ in vivo,

$$
\mathrm{Hb}-\mathrm{NH}_{2}+\mathrm{HN}=\mathrm{C}=\mathrm{O} \longrightarrow \mathrm{Hb}-\mathrm{NHCONH}_{2},
$$

and to elevate oxygen affinity of blood (KILMARTIN and Rossi-BERNARDI, 1969). The unreacted cyanate was rapidly decomposed to carbon dioxide and excreted through lung and urine with no or little irreversible damage to the organism (CERAMI et al., 1973). In this study, mice with high oxygen-affinity blood were obtained by oral uptake (ad libitum) of $0.5 \%$ NaCNO.

Exposure to hypoxia. Male mice of ICR strain aged 10 to 12 weeks were exposed to hypobaric hypoxia in groups of 4 to 6 mice. Hypobaric chamber was home-made from a commercially available airtight Plexiglas chamber and the extent of decompression was finely adjusted with a Teflon needle valve (Enoki et al., unpublished). Mice in the chamber were allowed to take food and water ad libitum during hypobaric exposure. The chamber was opened once a day for $15 \mathrm{~min}$ to clean and replenish with food and water.

Determination of blood oxygen affinity $\left(P_{50}\right)$. Oxygen dissociation curves (ODC) were constructed by a modification of the previously reported microtonometric method (KoHzUKi et al., 1983). Conventionally the $P_{50}\left(P_{\mathrm{O}_{2}}\right.$ for half-oxygenation of blood at pH 7.40, $P_{\mathrm{CO}_{2}} 40$ Torr, $37^{\circ} \mathrm{C}$ ) was computed by one-point procedure (ABERMAN et al., 1975). Blood gases $\left(\mathrm{pH}, P_{\mathrm{O}_{2}}, P_{\mathrm{CO}_{2}}\right.$ ) were determined by BMS3 Mk2 Blood Micro System (Radiometer, Copenhagen), and $S_{\mathrm{O}_{2}}$ by an oxygen saturation meter (OSM-2, Radiometer, Copenhagen).

Hematological determinations. Immediately after exposure to hypoxia, a drop of tail blood was obtained for reticulocyte count, and heparinized blood was drawn from inferior caval vein for determination of hematocrit $(\mathrm{Ht}), \mathrm{Hb}$ concentration, $P_{50}$, red cell 2,3-diphosphoglycerate (DPG) (MAEDA et al., 1971), and Epo.

Statistics. Unpaired Student's $t$-test was used to compare differences between the groups subjected to different degrees of hypoxia, and between the normal and cyanated groups.

\section{RESULTS}

\section{Plasma pretreatment}

Comparison of pretreatment procedures. The same plasma pooled from ICR strain mice was treated and assayed, and stimulatory and inhibitory activities (\%) were calculated:

$$
\% \text { stimulation }=\left\{\left(N_{x}-\bar{N}_{\min }\right) /\left(\bar{N}_{\max }-\bar{N}_{\min }\right)\right\} \times 100,
$$

where $N_{x}, \bar{N}_{\text {max }}$, and $\bar{N}_{\text {min }}$ are number of erythroid colonies formed in the culture media added test plasma, sufficient dose $(250 \mathrm{mU} / \mathrm{ml})$ of Epo, and only phosphate-buffered saline (without added Epo), respectively. $\bar{N}_{\max }$ and $\bar{N}_{\text {min }}$ are triplicate means. 


$$
\% \text { inhibition }=\left\{\left(\bar{N}_{\max }-N_{x}\right) /\left(\bar{N}_{\max }-\bar{N}_{\text {min }}\right)\right\} \times 100,
$$

where the higher \% represents higher content of inhibitor(s) in the plasma. Chloroform-dialysis (CD)-treated plasma showed the highest erythroid stimulation $(73.8 \pm 14.9 \%)$ and the lowest inhibition $(-12.0 \pm 3.9 \%)$. Therefore, CD pretreatment was used throughout in this study.

Comparison of CD-treated plasma and standard Epo. In Fig. 1, dose-response curves of CD-treated murine plasma and standard Epo are depicted. The dose-response curve for CD-treated plasma was linear and parallel to that of standard Epo from 1/4- to 1-fold concentrations, while the curve for untreated plasma showed an increasing inhibition upon increasing concentration of plasma. In view of these results, the Epo assays were performed with 2-fold-diluted CD-treated plasma. Since average \% recovery of 40.8 was found for the standard Epo by our present procedure, the obtained values of Epo potency were corrected by a factor of 0.408 .

Immunological identification of Epo in CD-treated plasma. As shown in Table 1, anti-human Epo monoclonal antibody (GоTO et al., 1989) abolished completely the colony-stimulating activity of standard Epo and plasma from normal and hypoxic mice. However, preincubation of the antibody with anti-mouse IgG goat antisera saved this activity perfectly. These results indicate that the colonystimulatory factor in CD-treated plasma is undoubtedly Epo.

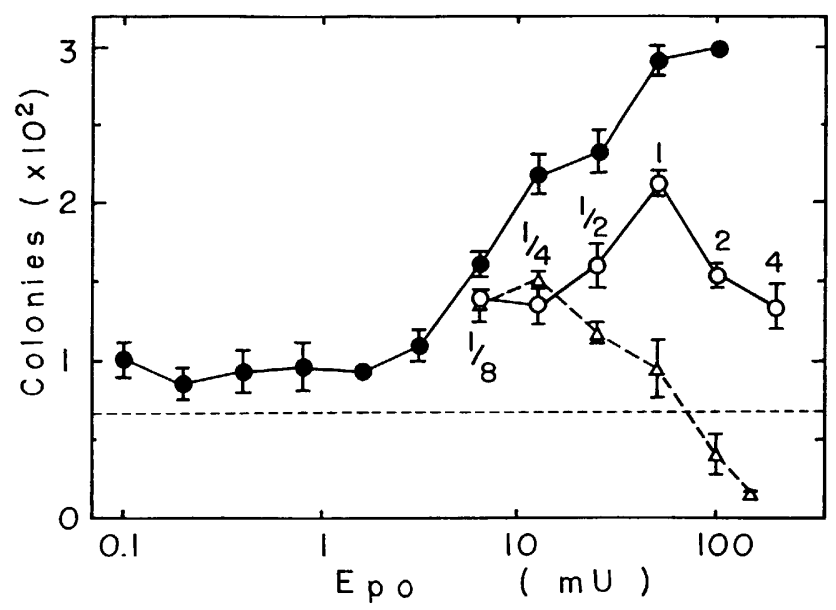

Fig. 1. Comparison of dose-response curves for standard erythropoietin (Epo), untreated, and chloroform-dialysis-treated normal mouse plasma. $\bullet$ standard Epo; $\triangle, \bigcirc$ untreated and chloroform-dialysis-treated normal mouse plasma, respectively, to which no Epo was added. Figures attached to the curves are the extent of concentration of the original plasma. Horizontal broken line indicates colony numbers with neither Epo nor plasma added. Vertical bars are \pm S.D. of the means. 
Table 1. Immunological identification of erythropoietin (Epo) in chloroform-dialysis-treated murine plasma.

\begin{tabular}{lr}
\hline & Colony counts \\
\hline Control (Epo 0 mU) & $79.7 \pm 4.1$ \\
1. Standard Epo & $205.7 \pm 8.2$ \\
Standard Epo + anti-Epo & $87.0 \pm 3.7$ \\
Standard Epo + anti-mouse IgG & $207.3 \pm 8.2$ \\
Standard Epo + (anti-Epo + anti-mouse IgG) & $208.7 \pm 5.0$ \\
2. Normal mouse plasma & $130.7 \pm 4.8$ \\
Normal mouse plasma + anti-Epo & $80.0 \pm 3.7$ \\
Normal mouse plasma + anti-mouse IgG & $128.0 \pm 2.4$ \\
Normal mouse plasma + (anti-Epo + anti-mouse IgG) & $129.3 \pm 3.4$ \\
3. Hypoxic mouse plasma & $150.7 \pm 2.5$ \\
Hypoxic mouse plasma + anti-Epo & $84.3 \pm 3.3$ \\
Hypoxic mouse plasma + anti-mouse IgG & $149.0 \pm 3.3$ \\
Hypoxic mouse plasma + (anti-Epo + anti-mouse IgG) & $149.3 \pm 4.0$ \\
\hline
\end{tabular}

Standard Epo, Connaught step 3 ovine Epo $250 \mathrm{mU} / \mathrm{ml}: 10 \mu \mathrm{l}$; anti-Epo, anti-human Epo monoclonal antibody $87.5 \mu \mathrm{g} / \mathrm{ml}: 10 \mu \mathrm{l}$; anti-mouse IgG, anti-mouse IgG goat serum $117 \mathrm{mg} / \mathrm{ml}: 10 \mu \mathrm{l}$. Normal and hypoxic ( 2 days at $0.46 \mathrm{~atm}$ ) mouse plasma was treated with chloroform-dialysis procedure. Values are mean \pm S.D.

\section{Preparation of mice with high oxygen-affinity blood by oral administration of cyanate}

Oral administration of cyanate and blood ODC. Figure 2 shows blood ODC $\left(\mathrm{pH} 7.40, P_{\mathrm{CO}_{2}} 40 \mathrm{Torr}, 37^{\circ} \mathrm{C}\right.$ ) of mice drinking $0.5 \% \mathrm{NaCNO}$ or the equimolar $(0.45 \%) \mathrm{NaCl}$. We found no difference between ODC of mice before and after drinking saline for 5 to 12 days, while there occurred significant left shift of ODC (higher oxygen affinity, lower $P_{50}$ ) depending on the drinking period of $\mathrm{NaCNO}$. Mice drinking cyanate for 8 days exhibited the highest oxygen affinity $\left(P_{50}=30.1 \pm 1.5\right.$ Torr, $\left.n=4\right)$ compared with the normal mice $\left(P_{50}=40.4 \pm 2.2\right.$ Torr, $n=10$ ) (Table 2 ), and this elevation of the oxygen affinity lasted even after 22 days. Cyanate drinking, however, gave rise to no alteration in the red cell 2,3-DPG.

Toxicity of NaCNO. Figure 3 shows temporal changes of body weight during and after drinking of cyanate. The finding that body weight decreased during drinking but after that increased rapidly, confirms the previous observation by Cerami et al. (1973). In view of these facts, the cyanated mice were allowed to drink water for two days after $\mathrm{NaCNO}$ period, and then used for experiments. The cyanated mice showed normal ranges of blood urea nitrogen of $25.5 \pm 1.7 \mathrm{mg} / \mathrm{dl}$ and serum creatinine concentration of $0.4 \pm 0.2 \mathrm{mg} / \mathrm{dl}$ (MITRUKA and RAWNSLEY, 1977). 


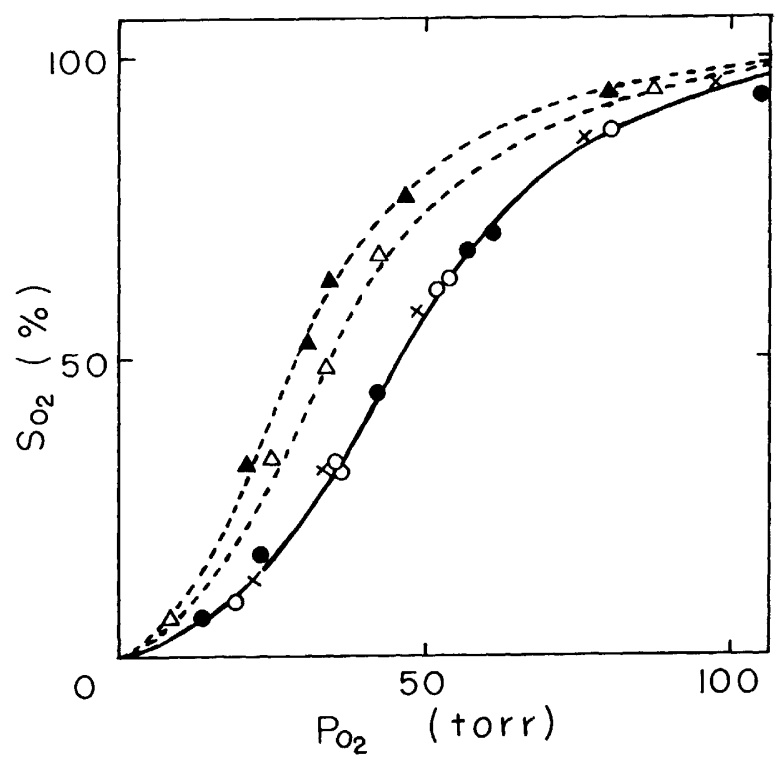

Fig. 2. Modification of oxygen dissociation curves ( $\left.\mathrm{pH} 7.40, P_{\mathrm{CO}_{2}} 40 \mathrm{Torr}, 37^{\circ} \mathrm{C}\right)$ of mouse blood by oral administration of cyanate. $\times$ control, drinking water; $O$ drinking $0.45 \% \mathrm{NaCl}$ for 5 days; $\bullet$ drinking $0.45 \% \mathrm{NaCl}$ for 12 days; $\triangle$ drinking $0.5 \% \mathrm{NaCNO}$ for 2 days; $\Delta$ drinking $0.5 \% \mathrm{NaCNO}$ for 8 days.

Table 2. Blood oxygen affinities $\left(P_{50}\right)$ and red cell 2,3-diphosphoglycerate contents (DPG) in normal and cyanated mice under normoxic and hypoxic conditions.

\begin{tabular}{cccccc}
\hline & \multicolumn{2}{c}{ Normal mice } & & \multicolumn{2}{c}{ Cyanated mice } \\
\cline { 2 - 3 } \cline { 5 - 6 } & $P_{50}($ Torr $)$ & $\begin{array}{c}\text { DPG } \\
(\mathrm{mmol} /(l \cdot \mathrm{RBC})\end{array}$ & & $P_{50}($ Torr $)$ & $\begin{array}{c}\text { DPG } \\
(\mathrm{mmol} /(l \cdot \mathrm{RBC}))\end{array}$ \\
\hline $\begin{array}{c}\text { Prehypoxic } \\
\text { 350 Torr }\end{array}$ & $40.4 \pm 2.2(10)$ & $8.38 \pm 0.48(10)$ & & $30.1 \pm 1.5(4)$ & $6.70 \pm 0.43(4)$ \\
$\quad$ 10 days & $38.2 \pm 1.7(6)$ & $6.75 \pm 0.46(6)$ & & $30.2 \pm 1.6(4)$ & $7.74 \pm 0.22(4)$ \\
200 Torr & & & & & \\
2 days & $41.6 \pm 3.2(4)$ & $8.92 \pm 0.38(5)$ & & $29.5 \pm 2.8(4)$ & $10.09 \pm 0.16(4)$ \\
10 days & $38.0 \pm 1.3(3)$ & $9.20 \pm 0.73(3)$ & & $29.4 \pm 1.4(3)$ & $7.82 \pm 1.09(3)$ \\
Average & $39.7 \pm 2.6(23)$ & $8.19 \pm 1.01(24)$ & $29.8 \pm 2.0(15)$ & $8.10 \pm 1.39(15)$ \\
\hline
\end{tabular}

Figures in parentheses refer to number of mice. $P_{50}$, oxygen tension for half-oxygenation of blood ( $\mathrm{pH} 7.40, P_{\mathrm{CO}_{2}} 40$ Torr, $\left.37^{\circ} \mathrm{C}\right)$. Values are mean \pm S.D. 


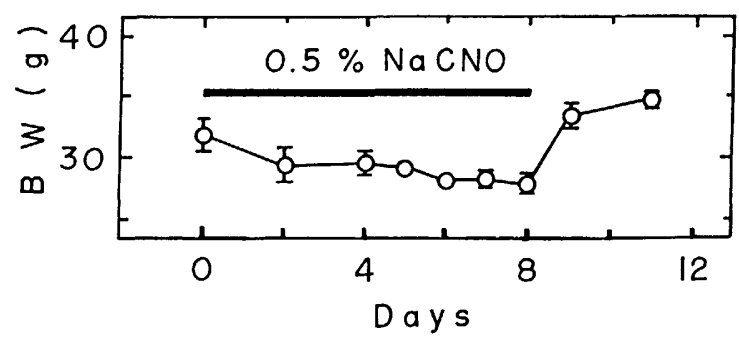

Fig. 3. Temporal changes of body weight in mice during and after cyanate drinking. Thick horizontal bar refers to cyanate drinking periods. Vertical bars are \pm S.D. of the quadruplicate means.

Hypoxia exposure, blood oxygen affinity, and plasma Epo level

Intensities of hypoxia were 350 Torr $(0.46 \mathrm{~atm}, 6,050 \mathrm{~m}$ simulated altitude, $P_{\mathrm{I}_{\mathrm{O}_{2}}}=62.9$ Torr $)$ and 200 Torr $\left(0.26 \mathrm{~atm}, 9,930 \mathrm{~m}\right.$ simulated altitude, $P_{\mathrm{I}_{\mathrm{O}_{2}}}=31.5$ Torr), and the duration was up to 10 days.

Three hundred and fifty Torr hypoxia exposure. Figure 4 shows temporal changes of Epo in normal and cyanated mice. In normal mice, plasma Epo titers increased significantly after a short lag, with the peak value of 4.1 -fold higher than the prehypoxic level at the 3rd day, and afterwards declined gradually regardless of the continuing exposure ( $p<0.05$ from the 6th hour to the 4th day as compared with the prehypoxic value) (Fig. 4, Table 3). In cyanated mice, plasma Epo titers elevated significantly ( 1.6 -fold, $p<0.05$ ) only at the 2 nd day. When comparing the hypoxic increments of plasma Epo in the two groups of mice, it should be noted that the Epo response to hypoxia was much less in the cyanated mice than in the normal mice from the 6th hour through the 10th day (Fig. 5).

Two hundred Torr hypoxia exposure. As shown in Fig. 4, roughly similar extent of increase was found in plasma Epo of the two groups of mice, the peak value being 5.2-fold elevated in the normal mice and 6.9-fold higher in the cyanated as compared with the prehypoxic level (Fig. 4, Table 3). Consequently, the Epo responses to hypoxia were not different from each other in the two groups (Fig. 6).

Intermittent exposure to 200 Torr hypoxia. As shown in Fig. 4 and Table 3, extents of the increase in plasma Epo under 350 and 200 Torr hypoxia were not so different from each other in normal mice. Since this might be due to damages of the Epo-producing renal tissues under severe hypoxia of 200 Torr (SCHUREK and KRIZ, 1985), this possibility was examined by observing the Epo production under intermittent exposure to 200 Torr. Both the normal and cyanated mice were exposed to 200 Torr hypoxia interrupted with normoxic period of $4 \mathrm{~h}$ a day. Plasma Epo in the intermittently hypoxic mice was essentially not different from that in the continuously hypoxic ones.

$\mathrm{Ht}$ and $\mathrm{Hb}$ concentration increased, 1.2- to 1.5 -fold in both normal and cyanated mice as compared with the prehypoxic values, from the 1st to 10th day under 


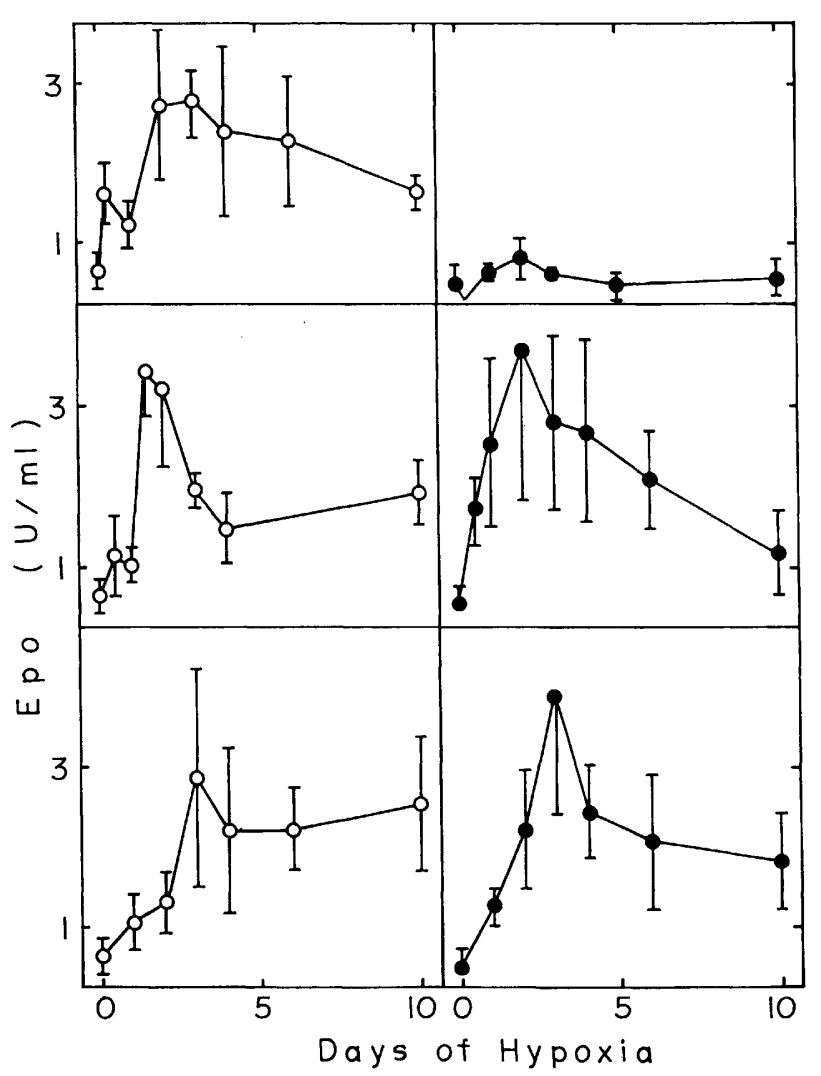

Fig. 4. Temporal changes of plasma erythropoietin in normal and cyanated mice exposed to hypobaric (top, 350 Torr; middle, 200 Torr; and bottom, intermittent 200 Torr) hypoxia. Normal $(O)$ and cyanated $(\bullet)$ mice. Vertical bars are \pm S.D. of the means.

hypoxia in all the exposures. Reticulocyte counts remained almost constant in cyanated mice under 350 Torr hypoxia, but increased significantly, 1.9- to 3.1-fold in normal and 1.3- to 1.8-fold in cyanated mice as compared with the prehypoxic values, in the other exposures.

Epo and erythroid colony-inhibiting factor $(s)$. While there is no doubt that Epo plays an important role for erythropoiesis, there is a possibility that inhibiting factor(s) may play some role in the regulation of erythropoiesis (Fig. 1). Therefore, the temporal changes of inhibiting factor(s) were determined and compared with that of plasma Epo in normal murine plasma during 350 Torr hypoxia exposure. Figure 7 shows that plasma Epo increased significantly after the 6th hour, with the peak at the 3 rd day, while the inhibitory activity decreased steadily and some recovery was found after 10 days $(p<0.01)$. 
Table 3. Temporal changes of plasma erythropoietin response to hypobaric hypoxia of 350 Torr, 200 Torr, and intermittent 200 Torr in normal and cyanated mice.

\begin{tabular}{|c|c|c|c|}
\hline \multirow{2}{*}{\multicolumn{2}{|c|}{$\begin{array}{l}\text { Duration of exposure } \\
\text { to hypoxia }\end{array}$}} & \multicolumn{2}{|c|}{ Plasma erythropoietin $(\mathrm{mU} / \mathrm{ml})$} \\
\hline & & Normal mice & Cyanated mice \\
\hline Prehypox & & $669 \pm 218(8)$ & $527 \pm 206(4)$ \\
\hline \multicolumn{4}{|c|}{350 Torr } \\
\hline 0.5 & & $909 \pm 473(3)$ & \\
\hline 1 & " & $623 \pm 127(3)$ & \\
\hline 6 & " & $1,620 \pm 395(4)^{*}$ & $331 \pm \quad 66(4)$ \\
\hline 1 & day & $1,225 \pm 306(6)^{*}$ & $650 \pm 105(4)$ \\
\hline 2 & days & $2,743 \pm 944(4)^{\#}$ & $838 \pm 245(9)^{\#}$ \\
\hline 3 & " & $2,755 \pm 422(4)^{*}$ & $637 \pm \quad 51(4)$ \\
\hline 4 & " & $2,402 \pm 1,066(4)^{\#}$ & \\
\hline 5 & " & & $502 \pm 176(3)$ \\
\hline 6 & " & $2,282 \pm 819(3)$ & \\
\hline 10 & " & $1,645 \pm 211(3)^{*}$ & $596 \pm 233(4)$ \\
\hline \multicolumn{4}{|c|}{200 Torr } \\
\hline 1 & $\mathrm{~h}$ & $417 \pm 127(4)$ & \\
\hline 12 & " & $1,162 \pm 505(4)^{\#}$ & $1,676 \pm 422(4)^{*}$ \\
\hline 1 & day & $1,044 \pm 208(3)^{\#}$ & $2,547 \pm 1,049(4)^{\#}$ \\
\hline 1.5 & days & $3,446 \pm 559(4)^{*}$ & \\
\hline 2 & " & $3,230 \pm 963(9)^{*}$ & $3,657 \pm 1,836(4)^{\#}$ \\
\hline 3 & " & $1,961 \pm 216(4)^{*}$ & $2,801 \pm 1,081(4)^{\#}$ \\
\hline 4 & " & $1,490 \pm 436(4)^{*}$ & $2,686 \pm 1,115(4)^{\#}$ \\
\hline 6 & " & & $2,100 \pm 600(4)^{*}$ \\
\hline 10 & " & $1,931 \pm 395(3)^{*}$ & $1,184 \pm 517(3)$ \\
\hline \multicolumn{4}{|c|}{200 Torr: intermittent } \\
\hline 1 & day & $1,061 \pm 348(6)^{\#}$ & $1,255 \pm 243(6)^{*}$ \\
\hline 2 & days & $1,311 \pm 397(6)^{*}$ & $2,225 \pm 735(6)^{*}$ \\
\hline 3 & " & $2,880 \pm 1,363(6)^{\#}$ & $3,929 \pm 1,498(6)^{*}$ \\
\hline 4 & " & $2,206 \pm 1,042(6)^{\#}$ & $2,456 \pm 593(6)^{*}$ \\
\hline 6 & " & $2,240 \pm 520(6)^{*}$ & $2,076 \pm 848(6)^{*}$ \\
\hline 10 & " & $2,554 \pm 843(4)^{\#}$ & $1,836 \pm 610(5)^{*}$ \\
\hline
\end{tabular}

Figures in parentheses refer to number of mice. ${ }^{*}$ Statistically different $(p<0.01)$ from prehypoxic values; "\#statistically different $(p<0.05)$ from prehypoxic values. Values are mean \pm S.D.

\section{DISCUSSION}

Plasma pretreatment. Epo bioassay is influenced by erythroid colonyformation inhibiting factor(s) in plasma (SAKATA et al., 1987). Therefore, it is necessary to remove the inhibitor(s) before Epo bioassay, and by comparison of 


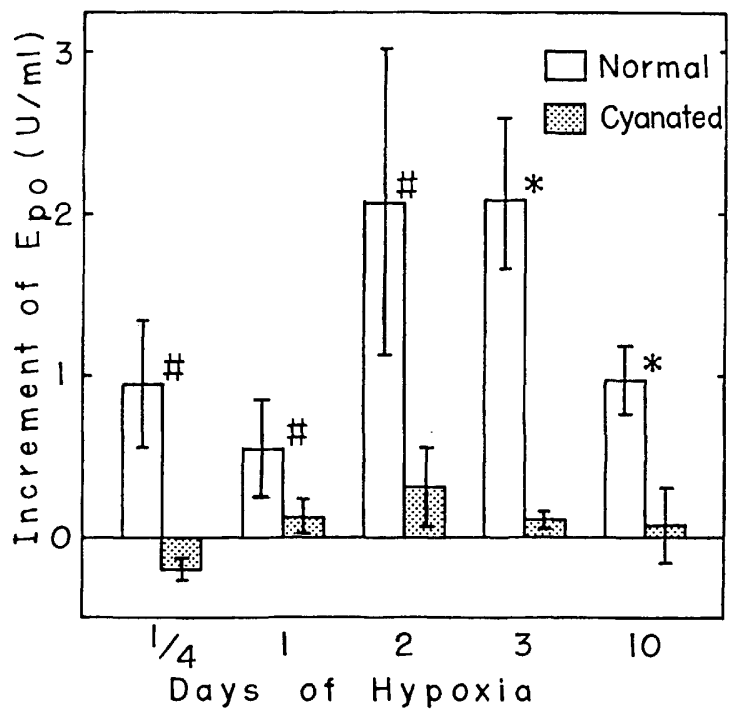

Fig. 5. Comparison of erythropoietin responses to hypobaric (350 Torr) hypoxia in normal and cyanated mice. * Statistically significant difference $(p<0.01)$ between two groups of mice; \#statistically significant difference $(p<0.05)$ between two groups of mice. Vertical bars are \pm S.D. of the means.

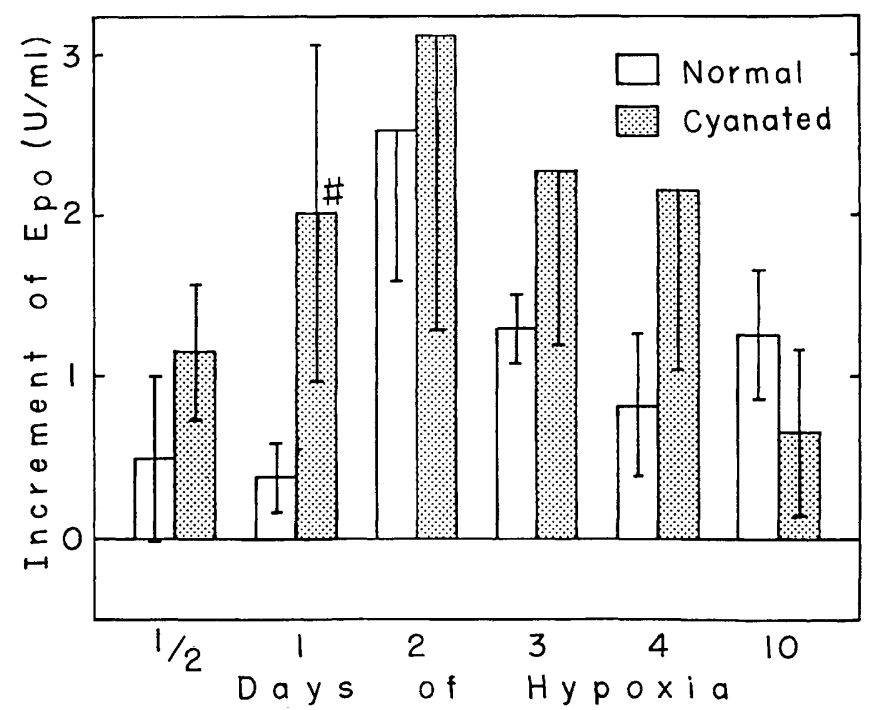

Fig. 6. Comparison of erythropoietin responses to hypobaric (200 Torr) hypoxia in normal and cyanated mice. \#Statistically significant difference $(p<0.05)$ between two groups of mice. Vertical bars are \pm S.D. of the means. 


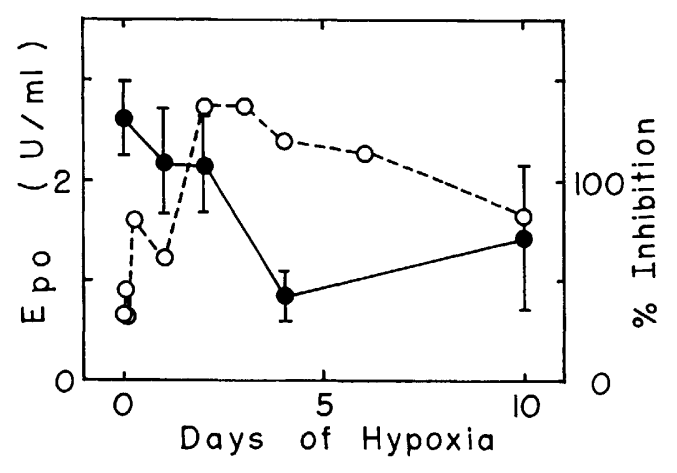

Fig. 7. Temporal correlation of plasma erythropoietin and erythroid colony inhibitor(s) in normal mice exposed to hypobaric (350 Torr) hypoxia. $\bigcirc$ plasma erythropoietin (cf. Fig. 4); $\bullet$ erythroid colony inhibitor(s). Vertical bars are \pm S.D. of the means.

the thirteen pretreatment procedures CD treatment was concluded to be the best for mouse plasma. The fact that acid-boiling-chloroform treatment is the best for human plasma (SAKATA et al., 1987) may reflect a species difference of the inhibitor(s). Dose-response examinations of $\mathrm{CD}$-treated murine plasma and standard Epo revealed that the 2-fold-diluted sample had no inhibitory activity while further-concentrated plasma brought more or less inhibitory effect on the colony formation (Fig. 1). Therefore, we used the CD-treated plasma after 2-fold dilution in the present Epo assays, although multiple dose-parallel line bioassay (DUNN and NAPIER, 1978) is more desirable for accuracy. Recently, it has become possible to prepare purified Epo (YanAGaWA et al., 1984) and to obtain reliable anti-Epo antibody. On using anti-Epo monoclonal antibody thus raised (Goto et al., 1989), we reexamined whether the stimulator bioassayed was Epo or not. It is evident that the stimulator in mouse plasma is Epo, and that it increases under hypoxia (Table 1).

Effect of cyanate administration. The elevation of blood oxygen affinity by $\mathrm{NaCNO}$ was 10 Torr in terms of $P_{50}$ (Table 2) and lasted for at least 22 days after discontinuation of $\mathrm{NaCNO}$. This latter fact seems to be somewhat strange in view of the previous finding that murine red cells undergo a random (exponential) decay with considerable short half-life (BURWELL et al., 1953). As 2,3-DPG content in red cells is unchanged (Table 2), the lower $P_{50}$ cannot be attributed to the change of 2,3-DPG content. Half-life of administered cyanate is shown to be very short (CERAMI et al., 1973), say 30 to $40 \mathrm{~min}$ in humans (BAUER et al., 1981). Therefore, mice drinking water for 2 days after discontinuation of $\mathrm{NaCNO}$ can be considered to suffer from no remaining effect of free cyanate. While most of administered $\mathrm{NaCNO}$ is rapidly excreted, cyanate that covalently binds to $\mathrm{N}$-termini of $\mathrm{Hb}$ brings forth persistent high oxygen affinity of blood (KILMARTIN and Rossi-Bernardi, 1969). As far as assessed by blood urea nitrogen and serum creatinine, function of 
the kidney, a principal Epo-producing organ, is not disturbed by $\mathrm{NaCNO}$ drinking. Reduction of water uptake in the cyanated mice $(1.5 \pm 0.4 \mathrm{ml} /($ day $\cdot$ mouse $)$ against $7.8 \pm 0.4 \mathrm{ml} /(\mathrm{day} \cdot \mathrm{mouse})$ in control) is thought to be partially responsible for body weight loss during $\mathrm{NaCNO}$ administration (Fig. 3).

Hypoxia exposure and Epo. Quite inconsistent findings have been reported in previous literature. The peak value of plasma Epo was observed at as early as $8 \mathrm{~h}$ of exposure to 4,200 $\mathrm{m}$ simulated altitude (SCARO et al., 1984), and after 2 days' exposure to either 5,440 m (DuNn et al., 1976) or 9,330 m (DunN et al., 1980) simulated altitude. Others reported the peak after $16 \mathrm{~h}$ at 5,440 $\mathrm{m}$ (FINNE, 1965) and at earlier time under more severe hypoxia (AвBRECHT and LiTTELL, 1972). The present results agree well with those by DunN et al. $(1976,1980)$ under comparable severities of hypoxia. The present result that mode of hypoxia (200 Torr) exposure, either continuous or intermittent, brought forth no difference in Epo production (Table 3) does not agree with that by Schooley and MaHLManN (1975) at 5,400 m. This can be interpreted as that the present hypoxia $(9,930 \mathrm{~m})$ was so severe that it might be hazardous to the Epo-producing tissues.

Blood oxygen affinity and plasma Epo: Blood oxygen affinity $\left(P_{50}\right)$ is one of the most important factors for oxygen homeostasis in a living organism, and the optimal $P_{50}$ value for oxygen transport is not fixed but depends on many factors, such as environmental $P_{\mathrm{O}_{2}}$. There have been few actual proofs for this contention, however, and few practical studies of this problem. Epo production has been believed to be regulated by hypoxic degrees, especially in renal tissues (JELKMANN, 1986a, b). Thus it might be possible to assess the optimal blood oxygen affinity by plasma Epo titers as an index of tissue hypoxia. In this context, strikingly different Epo response to 350 Torr hypoxia between normal and cyanated mice, which were not different in $\mathrm{Ht}$ and $\mathrm{Hb}$ concentration from each other (Fig. 4, Table 3), could be interpreted as that the elevated oxygen affinity $\left(P_{50}\right.$ : 30 Torr $)$ in the latter might be more optimal for oxygen transport in this intensity of hypoxia than the normal $P_{50}$ (40 Torr) in the former. Under more intense hypoxia of 200 Torr, this advantage of the higher oxygen affinity vanished, and we found similarly increased plasma Epo in both normal and cyanated mice (Fig. 4, Table 3). Similar studies but somewhat dissimilar results on normal and cyanated rats have been reported by LECHERMANN and JELKMANN (1985). They showed a significantly higher Epo in cyanated rats under normoxia and moderate hypoxia $(4,750 \mathrm{~m}$ simulated altitude), but we did not (Fig. 4, Table 3). This discrepancy can be attributed to species difference and also the different ways of $\mathrm{NaCNO}$ treatment. We used administration of $\mathrm{NaCNO}$ in which the elevation of blood oxygen affinity occurred so gradually that physiological compensatory mechanisms could intervene, while their way was exchange transfusion of $\mathrm{NaCNO}$-treated blood in which the acute elevation without physiological compensations might induce tissue hypoxia even under normoxic conditions.

Epo and erythroid colony inhibiting factor(s). As shown in Fig. 7, colony-inhibiting factor(s) decreased inversely to plasma Epo titers during hypoxia exposure. A possibility can be suggested that under hypoxia both of the increased 
colony-stimulating factor (Epo) and decreased inhibiting factor(s) may accelerate synergistically red cell production by bone marrow. At present, the nature of the inhibiting factor(s) remains to be clarified.

We are indebted to Dr. Masatsugu Ueda (Research Institute of Life Science, Snow Brand Milk Products Co., Ltd.) for his generous gift of anti-Epo monoclonal antibody.

This research was supported in part by Grants-in-Aid for Scientific Research ( $\# 61570050$ and 01570048) from the Ministry of Education, Science and Culture, Japan.

\section{REFERENCES}

AbBrecht, P. H. and Littell, J. K. (1972) Plasma erythropoietin in men and mice during acclimatization to different altitudes. J. Appl. Physiol., 32: 54-58.

Aberman, A., Cavanilles, J. M., Weil, M. H., and Shubin, H. (1975) Blood $P_{50}$ calculated from a single measurement of $\mathrm{pH}, P_{\mathrm{O}_{2}}$ and $S_{\mathrm{O}_{2}}$. J. Appl. Physiol., 38: 171-176.

Bauer, C., JelkmanN, W., and Moll, W. (1981) High oxygen affinity of maternal blood reduces fetal weight in rats. Respir. Physiol., 43: 169-177.

Burwell, E. L., Brickley, B. A., and Finch, C. A. (1953) Erythrocyte life span in small animals. Comparison of two methods employing radioiron. Am. J. Physiol., 172: $718-724$.

Cerami, A., Allen, T. A., Graziano, J. H., De Furia, F. G., Manning, J. M., and Gillette, P. N. (1973) Pharmacology of cyanate. I. General effects on experimental animals. J. Pharmacol. Exp. Ther., 185: 653-666.

Chan, S. H., Metcalf, D., and Stanley, E. R. (1971) Stimulation and inhibition by normal human serum of colony formation in vitro by bone marrow cells. $B r . J$. Haematol., 20: 329-341.

DUNN, C. D. R., JARVIS, J. H., and NAPIER, J. A. F. (1976) Changes in erythropoiesis and renal ultrastructure during exposure of mice to hypoxia. Exp. Hematol., 4: 365-381.

DunN, C. D. R. and NAPIER, J. A. F. (1978) Technical comments on the bioassay of erythropoietin. Exp. Hematol., 6: 577-584.

Dunn, C. D. R., Smith, L. N., Leonard, J. I., Andrews, R. B., and Lange, R. D. (1980) Animal and computer investigations into the murine erythroid response to chronic hypoxia. Exp. Hematol. (Suppl. 8), 8: 259-279.

FinNe, P. H. (1965) On the correspondence between red cell production and plasma erythropoietin levels. Scand. J. Clin. Lab. Invest., 17: 135-142.

Goto, M., Murakami, A., Akai, K., Kawanishi, G., Ueda, M., Chiba, H., and Sasaki, R. (1989) Characterization and use of monoclonal antibody directed against human erythropoietin that recognizes different antigenic determinants. Blood., 74: 1415-1423.

Granström, M. (1972) Studies on inhibitors of bone marrow colony formation in normal human sera and during a viral infection. Exp. Cell Res., 82 : 426-432.

Hebbel, R. P., Eaton, J. W., Kronenberg, R. S., Zanjani, E. D., Moore, L. G., and Berger, E. M. (1978) Human llamas. Adaptation to altitude in subjects with high hemoglobin oxygen affinity. J. Clin. Invest., 62: 593-600.

Jelkmann, W. (1986a) Erythropoietin research, 80 years after the initial studies by Carnot and Deflandre. Respir. Physiol., 63: 257-266.

Jelkmann, W. (1986b) Renal erythropoietin: Properties and production. Rev. Physiol., Biochem. Pharmacol., 104: 139-215.

Kilmartin, J. V. and Rossi-Bernardi, L. (1969) Inhibition of $\mathrm{CO}_{2}$ combination and 
reduction of the Bohr effect in haemoglobin chemically modified at its $\alpha$-amino groups. Nature, 222: 1243-1246.

Kohzuki, H., Enoki, Y., Sakata, S., and Tomita, S. (1983) A simple microtonometric method for whole blood oxygen dissociation curve and a critical evaluation of the "single point" procedure for blood $P_{50}$. Jpn. J. Physiol., 33: 987-994.

LAHIRI, S. (1975) Blood oxygen affinity and alveolar ventilation in relation to body weight in mammals. Am. J. Physiol., 229: 529-536.

LeChERMANN, B. and JelKmanN, W. (1985) Erythropoietin production in normoxic and hypoxic rats with increased blood $\mathrm{O}_{2}$ affinity. Respir. Physiol., 60: 1-8.

Maeda, N., Chang, H., Benesch, R., and Benesch, R. E. (1971) A simple enzymatic method for the determination of 2,3-diphosphoglycerate in small amounts of blood. $N$. Engl. J. Med., 284: 1239-1242.

Mitruka, B. M. and Rawnsley, H. M. (1977) Clinical Biochemical and Hematological Reference Values in Normal Experimental Animals, Masson Publ., New York, p. 72.

Najman, A., Guigon, M., Gorin, N.-C., and Mary, J.-Y. (eds.) (1987) The Inhibitors of Hematopoiesis, John Libbey \& Co., London, 356 pp.

Russell, E. S. and Keighley, G. (1972) The relation between erythropoiesis and plasma erythropoietin levels in normal and genetically anaemic mice during prolonged hypoxia or after whole-body irradiation. Br. J. Haematol., 22: 437-452.

Sakata, S., Enoki, Y., Nakatani, A., Kohzuki, H., Ohga, Y., and Shimizu, S. (1987) Plasma erythropoietin assay by a fetal mouse liver cell culture method with special reference to effective elimination of erythroid colony inhibitor(s) in plasma. Exp. Hematol., 15: 226-233.

Scaro, J. L., Miranda, C., Carrera, M. A., Martin, B., and Torrejon, I. (1984) Systemic oxygen transport and erythropoiesis in the mouse. Experientia, 40: 348-350.

SChooley, J. C. and MahlmanN, L.-J. (1975) Hypoxia and the initiation of erythropoietin production. Blood Cells, 1: 429-448.

SCHUREK, H.-J. and KRIZ, W. (1985) Morphologic and functional evidence for oxygen deficiency in the isolated perfused rat kidney. Lab. Invest., 53: 145-155.

Yanagawa, S., Hirade, K., Ohnota, H., Sasaki, R., Chiba, H., Ueda, M., and Goto, M. (1984) Isolation of human erythropoietin with monoclonal antibodies. J. Biol. Chem., 259: $2707-2710$. 